\title{
Pengelolaan Manajemen Risiko Sebagai Upaya Tindakan Preventif Pada Pembiayaan Mudharabah
}

\author{
Iwan Fahri Cahyadi \\ Institut Agama Islam Negeri Kudus \\ Itha2012@gmail.com
}

\begin{abstract}
Economic growth and development in a country can not be separated from the role of institutions in it, for example financial institutions. More and more healthy financial institutions indicate that a country's economic activities and productivity are very good. Benchmarks for growth and development can be seen from indicators including inflation rates below 5\%, falling unemployment, increasing Brutto Domestic Revenue (GDP), falling poverty numbers, increasing foreign exchange reserves, and so forth. Indonesia in 2017 is classified as a country that has prospective economic conditions, this can be seen from the economic indicators that are classified as good. So do not be surprised if financial institutions both banks and non-banks grow rapidly in Indonesia, Islamic finance institutions are no exception. Indonesia, with a population of nearly 260 million people consisting of $70 \%$ of the population of productive age (15-64 years) is a resource that cannot be ignored in driving the economy. For Islamic business this is a huge opportunity, this condition is also supported by almost the majority or the majority of Indonesia's Muslim population. Business is an activity that is always dealing with risk and return. Islamic banks are one business unit. Thus, Islamic banks will also face the risk of bank management itself. Even if it is examined more closely, Islamic banks are banks that are prerequisite for risk, because in carrying out their activities a lot is related to bank products that contain a lot of risk, such as mudharabah products. Likewise, the risk caused by dishonesty or cheating customers in conducting transactions. Therefore, sharia bank officials must be able to control risks to a minimum in order to obtain the optimum profit. There are at least 4 (four) matters relating to risks that need to be managed properly, namely market risk, financing risk, liquidity risk and operational risk. If these four things are able to be managed properly, then the success of the Islamic business will be able to grow and develop properly and be able to compete with other financial institutions.
\end{abstract}

Keywords: Risk Management, Mudharabah, Sharia, Financial Institutions, Business.

\begin{abstract}
Abstrak
Pertumbuhan dan perkembangan ekonomi di suatu negara tidak terlepas dari peran institusi di dalamnya, misalnya lembaga keuangan. Semakin banyak jumlah lembaga keuangan yang sehat mengindikasikan aktivitas dan produktivitas ekonomi suatu negara tersebut sangat baik. Tolok ukur pertumbuhan dan perkembangan dapat dilihat dari indikator diantaranya tingkat inflasi di bawah 5\%, turunnya jumlah angka pengangguran, Pendapatan Domestik Brutto (PDB) yang meningkat, turunnya jumlah angka kemiskinan, cadangan devisa bertambah, dan lain sebagainya. Indonesia pada tahun 2017 tergolong negara yang memiliki kondisi ekonomi yang prospektif, hal ini dapat dilihat dari indikator ekonomi yang tergolong baik. Maka tidak heran bila lembaga keuangan baik bank maupun non bank tumbuh pesat di Indonesia,
\end{abstract}


tidak terkecuali lembaga pembiayaan syariah. Indonesia, dengan jumlah penduduk hampir 260 juta jiwa yang terdiri dari $70 \%$ penduduknya berusia produktif (15-64 tahun) merupakan sumber daya yang tidak bisa diabaikan dalam menggerakkan roda perekonomian. Bagi bisnis syariah ini merupakan peluang yang sangat besar, kondisi ini juga didukung oleh hampir sebagian besar atau mayoritas penduduk Indonesia beragama islam. Bisnis adalah suatu aktivitas yang selalu berhadapan dengan resiko dan return. Bank syari' ah adalah salah satu unit bisnis. Dengan demikian, bank syari'ah juga akan menghadapi resiko manajemen bank itu sendiri. Bahkan kalau dicermati lebih mendalam, bank syari'ah merupakan bank yang syarat dengan resiko, karena dalam menjalankan aktivitasnya banyak berhubungan dengan produk-produk bank yang banyak mengandung resiko, seperti produk mudharabah. Demikian pula resiko yang diakibatkan karena ketidakjujuran atau kecurangan nasabah dalam melakukan transaksi. Oleh karena itu, para pejabat bank syari'ah harus dapat mengendalikan resiko seminimal mungkin dalam rangka untuk memperoleh keuntungan yang optimum. Paling tidak ada 4 (empat) hal yang berkenaan dengan resiko yang perlu dikelola secara baik, yaitu resiko pasar, resiko pembiayaan, resiko likuiditas dan resiko operasional. Apabila ke empat hal ini mampu di kelola dengan baik, maka keberhasilan bisnis syariah akan mampu tumbuh dan berkembang dengan baik serta mampu bersaing dengan lembaga pembiayaan lainnya.

Kata Kunci : Manajemen Resiko, Mudharabah, Syariah, Lembaga Keuangan, Bisnis.

\section{PENDAHULUAN}

Pertumbuhan dan perkembangan ekonomi di suatu negara tidak terlepas dari peran institusi di dalamnya, misalnya lembaga keuangan. Semakin banyak jumlah lembaga keuanganyang sehat mengindikasikan aktivitas dan produktivitas ekonomi suatu negara tersebut sangat baik. Kondisi ini menunjukkan bahwa kesadaran untuk berinvestasi baik di pasar uang dan pasar modal cukup tinggi, karena penduduknya memiliki dana berlebih untuk diinvestasikan, kemudian dana tersebut dikelola oleh lembaga keuangan agar dapat digunakan oleh para enterpreneur (pengusaha) untuk menambah permodalan dalam menjalankan dan ekspansi usahanya.

Fenomena ini pula yang sekarang terjadi di Indonesia, dengan jumlah penduduk hampir 260 juta jiwa yang terdiri dari $70 \%$ penduduknya berusia produktif (15-64 tahun) merupakan sumber daya yang tidak bisa diabaikan dalam menggerakkan roda perekonomian. Keberhasilan peran pemerintah dalam mengelola sumber daya manusia dan sumber daya alam dapat dilihat dari indikator perekonomian di Indonesia yang sangat baik beberapa tahun belakangan ini. Adapun indikator itu dapat dilihat dari tingkat inflasi di bawah 5\%, turunnya jumlah angka pengangguran, Pendapatan Domestik Brutto (PDB) yang 
meningkat, turunnya jumlah angka kemiskinan, cadangan devisa bertambah, dan lain sebagainya. Data Badan Pusat Statistik (BPS) tahun 2017 menunjukkan bahwa tren perekonomian di Indonesia cukup positif, stabil bahkan cenderung mengalami peningkatan.

\begin{tabular}{l|l|l}
\hline \multicolumn{3}{|c}{ Tabel 1. BPS 2017 } \\
\hline Tahun & 2016 & 2017 \\
\hline PDflasi & $3,0 \%$ & $3,5 \%$ (Perubahan Tahunan) \\
\hline Kemiskinan & $5,1 \%$ & $5,3 \%$ (Perubahan Tahunan) \\
\hline Pengangguran & $6,2 \%$ & $5,2 \%$ (dari Tenaga Kerja) \\
\hline Cadangan Devisa & 105,9 & 116,4 (dalam Miliar USD)
\end{tabular}

Data : BPS 2017

Stabilitas perekonomian di Indonesia juga tidak terlepas dari kondisi sosial politik dan keamanan yang terjaga, iklim investasi dan peraturan pemerintah yang kondusif untuk berinvestasi, sumber daya alam yang melimpah, serta tersedianya tenaga kerja yang mampu diterima pasar. Kondisi ini diperkuat dengan peran dan fungsi lembaga keuangan yang turut menggerakkan aktivitas perekonomian.

Bentuk peran pemerintah dalam mendukung keberadaan lembaga keuangan, khususnya perbankan diwujudkan melalui nasionalisasi bank peninggalan jaman penjajahan Belanda dahulu dan dalam bentuk peraturan perbankan yang secara berkala disempurnakan sesuai dengan situasi dan kondisi perubahan perekonomian dunia. Menurut Kasmir (2002), aktivitas perbankan yang pertama adalah menghimpun dana dari masyarakat luas yang dikenal dengan kegiatan funding, seperti tabungan, deposito, dan lainnya. Pengertian menghimpun dana maksudnya adalah mengumpulkan atau mencari dana dengan cara membeli dari masyarakat luas. Setelah memperoleh dana dalam bentuk simpanan dari masyarakat, maka oleh perbankan dana tersebut diputarkan kembali atau dijualkan kembali ke masyarakat dalam bentuk pinjaman atau kredit (lending). Dalam pemberian kredit juga dikenakan jasa pinjaman kepada penerima kredit (debitur). Dalam bentuk bunga dan biaya administrasi. Sedangkan bagi bank yang berdasarkan prinsip syari'ah dapat berdasarkan bagi hasil atau penyertaan modal.

Adapun peraturan pemerintah yang ter-up date mengenai dunia perbankan dituangkan dalam Undang-Undang RI nomor 10 tahun 1998 tanggal 10 November 1998 tentang perbankan, bahwa yang dimaksud 
dengan bank adalah "badan usaha yang menghimpun dana dari masyarakat dalam bentuk simpanan dan menyalurkannya kepada masyarakat dalam bentuk kredit dan bentuk-bentuk lainnya dalam rangka meningkatkan taraf hidup rakyat banyak".

UU No. 10 tahun 1998 ini sekaligus menghapus pasal 6 pada PP no. 72/1992 yang melarang dual sistem (membedakan fungsi beroperasinya satu bank). Dengan tegas pasal 6 UU no. 10 tahun 1998 membolehkan bank umum yang melakukan kegiatan secara konvensional dapat juga melakukan kegiatan usaha dengan berdasarkan prinsip syari'ah melalui :

a. Pendirian kantor cabang atau di bawah kantor cabang baru, atau

b. Pengubahan kantor cabang baru atau di bawah kantor cabang yang melakukan kegiatan usaha secara konvensional menjadi kantor yang melakukan kegiatan usaha berdasarkan prinsip syari'ah.

Keluarnya UU No. 10 tahun 1998 mendapat respon positif dari dunia perbankan, maka tidak heran dalam kurun waktu kurang dari 20 tahun jumlah bank syari'ah tumbuh dengan pesat. Berdasarkan data dari Otoritas Jasa Keuangan (OJK), hingga April 2016 jumlah bank syari'ah di Indonesia berjumlah 199 bank syari'ah yang terdiri dari 12 Bank Umum Syari'ah (BUS), 22 Unit Usaha Syari'ah (UUS), dan 165 Bank Pembiayaan Rakyat Syari'ah (BPRS). Pertumbuhan bank syari'ah yang begitu pesat dan signifikan ini juga tidak terlepas para pengelola bank syari'ah dalam membaca pangsa pasar di Indonesia yang mayoritas (80\%) penduduknya menganut agama Islam.

Sebagai seorang muslim tentunya dalam perniagaan maupun berinvestasi membutuhkan lembaga pembiayaan yang sesuai dengan syari'ah islam. Dasar pijakan ekonomi umat adalah upaya mewujudkan hubungan manusia yang islami di antara para pihak yang melakukan berbagai transaksi atau akad dan perikatan. Semangat dan etika ekonomi islami menekankan pada kepentingan bersama melalui pertukaran manfaat (taba'dul al-mana'fi) atas dasar saling merelakan (an tara'dlin); saling menguntungkan (murabahah); saling mempercayai (amanah); dan bekerja sama (musyarakah); dalam berbagai bentuknya. Semua tindakan itu dilakukan dengan penuh kerelaan (ikhlash) atas dasar tauhidullah dan persaudaraan (ukhuwah) sehingga tiada gharar, maisir, riba dan ihtikar. Persaudaran di sini meliputi dua bentuk, yaitu persaudaraan berdasarkan kesamaan keyakinan (ukhuwah islamiyah), dan persaudaraan berdasarkan kesamaan derajat manusia (ukhuwah insaniyah). Sifat mengutamakan kepentingan pribadi atau dorongan untuk mendapatkan keuntungan semata-mata, tidak tercermin dalam ekonomi Islam, karena ekonomi umatik berlandaskan prinsip-prinsip islami (Juhaya, 2012).

Seperti kita ketahui, bahwa dalam Islam melarang perniagaan yang mengandung(1) Riba, yaitu bentuk tambahan yang disyaratkan dari 
transaksi pinjam-meminjam uang seperti bunga, dan setiap tambahan dari transaksi pertukaran barang ribawi, seperti pertukaran uang sejenis secara tunai atau tangguh dan pertukaran uang yang tidak sejenis secara tunai. Jadi disini uang dijadikan sebagai komoditi, (2) Dzulm, atau kezaliman yang merupakan lawan dari 'adl atau keadilan, yaitu menempatkan sesuatu tidak pada tempatnya, memberikan sesuatu tidak pada tempatnya, memberikan sesuatu tidak sesuai yang bukan haknya, dan memperlakukan sesuatu tidak pada posisinya, misalnya Bank Syariah yang mengurangi nisbah bagi hasil nasabah penabung tanpa sepengetahuan nasabah yang bersangkutan; (3). Maysir adalah setiap transaksi yang bersifat spekulatif dan tidak berkaitan dengan produktifitas serta bersifat perjudian (gambling), seperti transaksi forex trading untuk tujuan spekulatif; (4) Gharar, yaitu setiap transaksi yang dapat merugikan pihak yang bertransaksi karena mengandung unsur ketidakjelasan, ketidakpastian, manipulasi dan eksploitasi informasi oleh pihak tertentu, dan (5). Haram adalah segala sesuatu yang diharamkan dalam al-Qur'an dan Sunnah, seperti transaksi jual-beli babi, minuman keras, narkoba dan bangkai.

Menurut Kasmir (2004), untuk merealisasikan tujuan mulia tersebut berdasarkan prinsip islami, maka produk-produk bank syari'ah meliputi :

1. Al-Wadi'ah (Simpanan)

Al-Wadi'ah merupakan titipan atau simpanan pada bank syari'ah. Prinsip al-Wadi'ah merupakan titipan murni dari satu pihak ke pihak lain, baik perorangan maupun badan hukum yang harus dijaga dan dikembalikan kapan saja bila si penitip menghendaki. Penerima simpanan disebut yad al-amanah yang artinya tangan amanah. Si penyimpan tidak bertanggung jawab atas segala kehilangan dan kerusakan yang terjadi pada titipan selama hal itu bukan akibat dari kelalaian atau kecerobohan yang bersangkutan dalam memelihara barang titipan.

Akan tetapi dewasa ini agar uang yang dititipkan tidak menganggur begitu saja, oleh si penyimpan uang titipan tersebut (bank syar'ah) digunakan untuk kegiatan perekonomian. Tentu saja penggunaan uang titipan harus terlebih dulu meminta izin kepada si pemilik uang dan dengan catatan si pengguna uang menjamin akan mengembalikan uang tersebut secara utuh. Dengan demikian prinsip yad al-amanah (tangan amanah) menjadi yad adh-dhamanah (tangan penanggung). Mengacu pada prinsip yad adh-dhamanah bank sebagai penerima dana dapat memanfaatkan dana titipan seperti simpanan giro dan tabungan, dan deposito berjangka untuk dimanfaatkan bagi kepentingan masyarakat dan kepentingan negara. 
Yang terpenting dalam hal ini si penyimpan bertanggung-jawab atas segala kehilangan dan kerusakan yang menimpa uang tersebut.

Konsekuensi dari diterapkannya prinsip yad adh-dhamanah pihak bank akan menerima seluruh keuntungan dari penggunaan uang, namun sebaliknya bila mengalami kerugian juga harus ditanggung oleh bank. Sebagai imbalan kepada pemilik dana disamping jaminan keamanan uangnya juga akan memperoleh fasilitas lainnya seperti insentif atau bonus untuk giro wadiah. Artinya bank tidak dilarang untuk memberikan jasa atas pemakaian uang berupa insentif atau bonus, dengan catatan tanpa perjanjian terlebih dulu baik nominal maupun persentase dan ini murni merupakan kebijakan bank sebagai pengguna uang. Pemberian jasa berupa insentif atau bonus biasanya digunakan istilah nisbah atau bagi hasil antara bank dengan nasabah. Bonus biasanya diberikan kepada nasabah yang memiliki dana ratarata minimal yang telah ditetapkan.

Dalam praktiknya nisbah antara bank (shahibul maal) dengan deposan (mudharib) berupa bonus untuk giro wadiah sebesar 30\%, nisbah 40:60 untuk tabungan dan nisbah 45:55 untuk simpanan deposito.

2. Pembiayaan dengan Bagi Hasil

Penyaluran dana dalam bank konvensional, kita kenal dengan istilah kredit atau pinjaman. Sedangkan dalam bank syari'ah untuk penyaluran dananya kita kenal dengan istilah pembiayaan. Jika dalam bank konvensional keuntungan bank diperoleh dari bunga yang dibebankan, maka dalam bank syari'ah tidak ada istilah bunga, akan tetapi bank syari'ah menerapkan sistem bagi hasil. Prinsip bagi hasil dalam bank syari'ah yang diterapkan dalam pembiayaan dapat dilakukan dalam 4 akan utama, yaitu :

- Al-Musyarakah

- Al-Mudharabah

- Al-Muza'arah

- Al-Musaqah

Untuk lebih jelasnya keempat macam prinsip utama bagi hasil dalam bank syariah di atas akan diurakan sebagai berikut:

a. Al-Musyarakah

Al-Musyarakah merupakan akad kerjasama antara dua pihak atau lebih untuk melakukan usaha tertentu. Masing-masing pihak memberikan dana atau amal dengan kesepakatan bahwa keuntungan atau resiko akan ditanggung bersama sesuai dengan kesepakatan.

Dalam praktek perbankan al-Musyarakah diaplikasikan dalam hal pembiayaan proyek. Nasabah yang dibiayai dengan bank sama- 
sama menyediakan dana untuk melaksanakan proyek tersebut. Keuntungan dari proyek dibagi sesuai dengan kesepakatan untuk bank setelah terlebih dahulu mengembalikan dana yang dipakai nasabah. Al-Musyarakah dapat pula dilakukan untuk kegiatan investasi seperti pada lembaga keuangan modal ventura.

b. Al-Mudharabah

Al-Mudharabah merupakan akad kerja sama antara dua pihak, dimana pihak pertama menyediakan seluruh modal dan pihak lain menjadi pengelola. Keuntungan dibagi menurut kesepakatan yang dituangkan dalam kontrak. Apabila rugi maka akan ditanggung pemilik modal selama kerugian itu bukan akibat dari kelalaian si pengelola. Apabila kerugian diakibatkan kelalaian pengelola, maka si pengelolalah yang bertanggung-jawab.

Dalam praktiknya mudharabah terbagi dalam 2 jenis yaitu mudharabah muthlaqah dan mudharabah muqayyah. Pengertian mudharabah muthlaqah merupakan kerjasama antara pihak pertama dan pihak lain yang cakupannya lebih luas. Maksudnya tidak dibatasi oleh waktu, spesifikasi usaha dan daerah bisnis. Sedangkan mudharabah muqayyah merupakan kebalikan dari mudharabah muthlaqah dimana pihak lain dibatasi oleh waktu spesifikasi usaha dan daerah bisnis.

Dalam dunia perbankan Al-Mudharabah biasanya diaplikasikan pada produk pembiayaan atau pendanaan seperti, pembiayaan modal kerja. Dana untuk kegiatan mudharabah diambil dari simpanan tabungan berjangka seperti tabungan haji atau tabungan kurban. Dana juga dapat dilakukan dari deposito biasa dan deposito spesial yang dititipkan nasabah untuk usaha tertentu.

c. Al-Muza'arah

Al-Muza'arah merupakan kerjasama pengolahan pertanian antara pemilik lahan dengan penggarap. Pemilik lahan menyediakan lahan kepada penggarap untuk ditanami produk pertanian dengan imbalan bagian tertentu dari hasil panen. Dalam dunia perbankan kasus ini diaplikasikan untuk pembiayaan bidang platation ata dasar bagi hasil panen.

Pemilik lahan dalam hal ini menyediakan lahan, benih dan pupuk. Sedangkan penggarap menyediakan keahlian, tenaga, dan waktu. Keuntungan diperoleh dari hasil panen dengan imbalan yang telah disepakati.

d. Al-Musaqah

Pengertian Al-Musaqah adalah bagian dari Al-Muza'arah yaitu penggarap hanya bertanggung jawab atas penyiraman dan pemeliharaan dengan menggunakan dana dan peralatan mereka 
sendiri. Imbalan tetap diperoleh dari persentase hasil panen pertanian. Jadi tetap dalam kontek adalah kerjasama pengolahan pertanian antara pemilik lahan dengan penggarap.

\section{Bai'al-Murabahah}

Bai'al-Murabahah merupakan kegiatan jual beli pada harga pokok dengan tambahan keuntungan yang disepakati. Dalam hal ini penjual harus terlebih dahulu memberitahukan harga pokok yang ia beli ditambah keuntungan yang diinginkannya.

4. Bai'as-salam

Bai'as-salam adalah pembelian barang yang diserahkan kemudian hari, sedangkan pembayaran dilakukan dimuka. Prinsip yang harus dianut adalah harus diketahui terlebih dahulu jenis, kualitas dan jumlah barang dan hukum awal pembayaran harus dalam bentuk uang.

5. Bai'Al-istihna'

Bai'Al-Istihna' adalah bentuk khusus dari akad Bai'as-salam, oleh karena itu ketentuan dalam Bai'Al-istihna' mengikuti ketentuan dan aturan Bai'as-Salam. Pengertian Bai'Al-istihna' adalah kontrak penjualan antara pembeli dengan produsen (pembuat barang). Kedua belah pihak harus saling menyetujui atau sepakat lebih dulu tentang harga dan sistem pembayaran. Kesepakatan harga dapat dilakukan tawar menawar dan sistem pembayaran dapat dilakukan di muka atau secara angsuran per bulan atau di belakang.

6. Al-Ijarah (Leasing)

Al-ljarah merupakan akad pemindahan hak guna atas barang atau jasa, melalui pembayaran upah sewa, tanpa diikuti dengan pemindahan kepemilikan atas barang itu sendiri. Dalam praktiknya kegiatan ini dilakukan oleh perusahaan leasing, baik untuk kegiatan operating lease maupun financial lease.

7. Al-Wakalah (Amanat)

Wakalah atau wakilah artinya penyerahan atau pendelegasian atau pemberian mandat dari satu pihak kepada pihak lain. Mandat ini harus dilakukan sesuai dengan yang telah disepakati oleh si pemberi mandat.

8. Al-Kafalah (Garansi)

Pengertian al-Kafalah adalah jaminan yang diberikan penanggung kepada pihak ketiga untuk memenuhi kewajiban pihak kedua atau yang ditanggung. Dapat pula diartikan sebagai pengalihan tanggung jawab dari satu pihak kepada pihak lain. Dalam dunia perbankan dapat dilakukan dalam hal pembiayaan dengan jaminan seseorang.

9. Al-Hawalah

Al-Hawalah merupakan pengalihan utang dari orang yang berutang kepada orang lain yang wajib menanggungnya. Atau dengan kata lain 
pemindahan beban utang dari satu pihak kepada pihak lain. Dalam dunia keuangan atau perbankan dikenal dengan kegiatan anjak piutang atau factoring.

10. Ar-Rahn

Ar-Rahn adalah kegiatan menahan salah satu harta milik si peminjam sebagai jaminan atas pinjaman yang diterimanya. Kegiatan seperti ini dilakukan seperti jaminan utang atau gadai.

Dalam mengelola produk-produk tersebut meskipun bank syari'ah semata-mata tidak hanyaberorientasi kepada keuntungan (ada unsur sosial), namun bagaimanapun juga tanpa keuntungan (bagi hasil, jual beli, sewa menyewa) tidak mungkin lembaga ini mampu beroperasi. Oleh karena itu, diperlukan pengelolaan yang profesional dengan menerapkan prinsip kehati-hatian harus diutamakan. Kondisi ini perlu mendapat perhatian serius mengingat beberapa tahun belakangan ini tingkat kemacetan pembiayaan (Non Performing Finance/NPF) bank syari'ah lebih tinggi dibandingkan dengan bank konvensional (Non Performance Loan/NPL). Dari data Otoritas Jasa Keuangan merilis sejak triwulan IV 2016 hingga Oktober 2017 angka NPF bank syari'ah berada di angka 4,12\%. Angka ini jauh melampaui NPL bank konvensional sebesar 2,96\%. Kondisi ini merupakan warningbagi pengelola bank syari'ah, terutama untuk produk pembiayaan yang berisiko besar seperti pembiayaan mudharabah, karena bank syari'ah menyertakan seluruh modal berupa uang secara tunai dan 100\% kepada pihak pengelola usaha (mudharib), sehingga bila pihak yang dipercaya untuk mengelola usaha itu tidak berhasil maka bank syari'ah akan menanggunga dan mengalami kerugian yang sangat besar. Oleh karena ini, meskipun bank syari'ah menyediakan produk mudharabah, namun dalam realitanya banyak dari lembaga ini yang sedikit proporsi (prosentasenya) untuk melakukan pembiayaan jenis ini dibandingkan dengan jenis produk pembiayaan lainnya, karena resikonya terlalu besar. Melihat fenomena ini alangkah baiknya apabila peran manajemen resiko perlu dikedepankan sebelum melakukan pembiayaan produk bank syari'ah, khususnya pembiayaan mudharabah.

\section{PEMBAHASAN}

\section{Diskripsi Pembiayaan Mudharabah}

Menurut Ascarya (2006), prinsip pokok (standar) minimal pembiayaan mudharabah yang harus dipenuhi adalah sebagai berikut :

a. Mudharabah adalah suatu pengaturan ketika seseorang berpartisipasi dengan menyediakan sumber pendanaan atau uangnya dan pihak lainnya menyediakan tenaganya, dan dengan mengikutsertakan bank, unit trust, reksadana, atau institusi, dan orang lainnya. 
b. Seorang mudharib yang menjalankan bisnis dapat diartikan sebagai orang pribadi, sekumpulan orang, atau suatu badan hukum dan badan usaha.

c. Rabbul Mal harus menyediakan investasinya dalam bentuk uang atau sejenisnya, selain daripada piutang, dengan nilai valuasi yang disepakati bersama yang dilimpahkan pengelolaan sepenuhnya pada mudharib.

d.Pengelolaan usaha mudharabah harus dilakukan secara eksklusif oleh mudharib dengan kerangka mandat yang ditetapkan dalam kontrak mudharabah.

e. Keuntungan harus dibagi dalam suatu proporsi yang disepakati pada awal kontrak dan tidak boleh ada pihak yang berhak untuk memperoleh nilai imbalan atau renumerasi yang ditetapkan dimuka.

f. Kerugian finansial dari kegiatan usaha mudharabah harus ditanggung oleh rabbul mal, kecuali jika terbukti mudharib melakukan kecurangan, kelalaian atau kesalahan dalam mengelola secara sengaja atau bertindak tidak sesuai dengan mandat yang telah ditetapkan dalam perjanjian mudharabah.

g. Kewajiban dari rabbul mal terbatas sebesar nilai investasinya kecuali dinyatakan lain dalam kontrak mudharabah.

h. Mudharabah dapat bervariasi tipenya yang dapat dengan satu atau banyak tujuan bergulir atau periode tertentu, restricted atau unrestricted, close atau open-ended tergantung dengan kondisi yang ditetapkan.

i. Mudharib dapat menginvestasikan dananya dalam bisnis mudharabah dengan persetujuan rabbul mal. Persyaratannya adalah rabbul mal tidak boleh memperoleh porsi keuntungan lebih besar daripada porsi investasinya terhadap totap investasi proyek mudharabah. Kerugian harus dibagi sesuai dengan proporsi modal dari masing-masing pihak.

Dari uraian di atas maka ruang lingkuppembiayaan mudharabah dikenal skim yang penting oleh bank syari'ah dalam hubungannya dengan deposan yang menyerahkan uangnya ke bank sebagai pemilik modal. Uang ini diinvestasikan oleh bank sebagaimudharib dengan dasar bagi hasil sesuai rasio yang telah disepakati bersama.

Bank syari'ah menggunakan skim ini biasanya untuk membiayai profesional seperti dokter, insiyur, pedagang atau pengrajin. Bank menyediakan pembiayaan yang diperlukan sebagai pemilik modal dan akan mendapatkan bagian keuntungan yang telah disepakati bersama.

Perlu dicatat bahwa skim ini memiliki resiko tinggi bagi bank karena bank menyerahkan modal kepada mudharib yang menjalankan 
usaha dan manajemen, mudharib bertanggung jawab terhadap kerugian hanya jika ia lalai. Untuk itu bank syari'ah perlu mengambil langkahlangkah pencegahan untuk meminimalkan resiko dan memastikan eksekusi transaksi mudharabah lebih baik.

\section{Diskripsi Manajemen Resiko}

Setiap kehidupan senantiasa dihadapkan dengan resiko, baik itu secara individual dalam kehidupan sehari-hari, maupun dalam berbisnis. Pengertian resiko adalah "Risk is condition, in which there is is possibility of an adverse deviation from a desired outcome that is expected or hopefore" (Vaugh, 1997) atau "risk is the certainly that expected outcomes will not to fullfill" (Jones, 2002). Bagi seorangrisk taker, maka resiko adalah tantangan, bukan halangan. Mereka berusaha mengenali resiko yang ada, kemudian memperhitungkan untung dan ruginya untuk dijadikan dasar keputusan menghadapi resiko tersebut dan mengubah resiko menjadi peluang dan keberhasilan.

Menurut Sonni Dwiharsono (1996), pengertian dari resiko paling tidak ada tiga point yaitu (1). Kerugian yang tidak diharapkan, yaitu ketika lembaga pembiayaan menginvestasikan modalnya (pemberian kredit) kepada mudharib justru proyek tersebut mengalami kegagalan. (2). Penyimpangan dari yang diharapkan, yaitu apa yang telah direncanakan sejak awal (seharusnya) tidak sesuai dengan realita yang ada (sebenarnya). Meskipun secara keseluruhan pembiayaan itu tidak gagal total, namun bagi hasil yang direncanakan tidak memenuhi target. (3). Kejadian yang tidak menguntungkan, yaitu adanya peristiwa eksternal yang menyebabkan dampak negatif terhadap proyek yang di biayai, misalnya banjir, gempa bumi, kerusuhan, dan lainnya yang mana perusahaan tidak punya kapasitas untuk menanggulangi (force majeure). Jadi kejadian ini tidak disebabkan oleh kesalahan atau kelalaian mudharib.

Menurut Muhammad (2011), Bisnis adalah suatu aktivitas yang selalu berhadapan dengan resiko dan return. Bank syari'ah adalah salah satu unit bisnis. Dengan demikian, bank syari'ah juga akan menghadapi resiko manajemen bank itu sendiri. Bahkan kalau dicermati lebih mendalam, bank syari'ah merupakan bank yang syarat dengan resiko, karena dalam menjalankan aktivitasnya banyak berhubungan dengan produk-produk bank yang banyak mengandung resiko, seperti produk mudharabah. Demikian pula resiko yang diakibatkan karena ketidakjujuran atau kecurangan nasabah dalam melakukan transaksi. Oleh karena itu, para pejabat bank syari'ah harus dapat mengendalikan resiko seminimal mungkin dalam rangka untuk memperoleh keuntungan yang optimum.

Meskipun manajer bank berusaha untuk menghasilkan keuntungan setinggi-tingginya, secara simultan mereka harus juga memerhatikan adanya kemungkinan resiko yang timbul menyertai keputusan-keputusan 
manajemen tentang struktur asset dan liabilitasnya. Secara spesifik resikoresiko yang akan menyebabkan bervariasinya tingkat keuntungan bank meliputi resiko likuiditas, resiko kredit, resiko tingkat bunga dan resiko modal. Bank syari'ah tidak akan menghadapi resiko tingkat bunga, walau dalam lingkungan dimana berlaku dual banking system meningkatnya tingkat bunga di pasar konvensional dapat berdampak pada meningkatnya resiko likuiditas sebagai akibat adanya nasabah yang menarik dana dari bank syari'ah dan berpindah ke bank konvensional.

Secara garis besar jenis resiko itu juga dapat dibedakan atas dua kelompok besar yaitu :

a. Resiko yang sistematis, yaitu resiko yang diakibatkan oleh adanya kondisi atau situasi tertentu yang bersifat makro, seperti perubahan situasi politik, perubahan kebijakan ekonomi pemerintah, perubahan situasi pasar, situasi krisis atau resesi, dan sebagainya yang berdampak pada kondisi ekonomi secara umum;

b. Resiko yang tidak sistematis, yaitu resiko yang unik, yang melekat pada suatu perusahaan atau bisnis tertentu saja. Perbankan syari'ah juga berpotensi menghadapi resiko-resiko tersebut, kecuali resiko tingkat bunga, karena Perbankan Islam tidak akan berurusan dengan bunga.

Di sisi lain, pembiayaan bank syari'ah dilihat dari perolehan hasil dapat digolongkan menjadi dua, yaitu : (1). Pembiayaan yang memberikan perolehan (hasil) tetap dan (2) Pemberian yang memberikan perolehan (hasil) tidak tetap. Pembiayaan yang memberikan hasil tetap didapatkan dari pembiayaan yang berakad jual beli (tijarah) dan sewa menyewa (ijarah). Sementara pembiayaan yang memberikan hasil tidak tetap didapatkan dari pembiayaan yang berakad bagi hasil (syirkah). Berdasarkan kondisi tersebut maka pembiayaan di bank syari'ah akan memberikan resiko yang berbeda antara akad yang satu dengan lainnya.

Kontrak mudharabah dijalankan oleh bank syari'ah merupakan suatu kontrak peluang investasi yang mengandung resiko tinggi. Sebab model kontrak tersebut sarat dengan asymmetric information. Asimetrik informasiadalah kondisi yang menunjukkan sebagian investor mempunyai informasi dan yang lainnya tidak memilikinya. Asimetrik informasi yang dilakukan agen dalam kontrak keuangan biasanya berbentuk moral hazard dan adverse selection. Adapun yang dimaksud adverse selection adalah terjadi pada kontrak utang ketika peminjam memiliki kualitas yang tidak baik atas kredit di luar batas ketentuan tingkat keuntungan tertentu, dan moral hazard terjadi ketika melakukan penyimpangan atau menimbulkan resiko yang lebih besar dalam kontrak.

Dalam kontrak mudharabah, ketika proses produksi dimulai, maka agen (mudharib) menunjukkan etika baiknnya atas tindakan yang telah 
disepakati bersama. Namun setelah berjalan, tidak menutup kemungkinan akan muncul tindakan yang tidak terkendalikan, yaitu moral hazard (tindakan yang tidak dapat diamati) dan adverse selection (etika pengusaha yang secara melekat tidak dapat diketahui oleh pemilik modal). Dari uraian di atas, terlihat bahwa masalah asimetrik informasi adalah sangat berhubungan dengan masalah keuangan atau investasi. Terlebih lagi jika dikaitkan dengan kontrak keuangan mudharabah.

Tingkat adverse selection dan moral hazard adalah berhubungan langsung dengan tingkat asimetrik informasi dan ketidaklengkapan pasar. Sehubungan dengan itu maka bank syari'ah harus memiliki alat screening untuk mengurangi asimetrik informasi yang akan terjadi dalam pembiayaan mudharabah. Agar dalam kontrak mudharabah dapat diminimalkan resiko dan terjadi maksimal hasilnya, maka pihak bank syari'ah perlu melakukan upaya-upaya pencegahan, misalnya melalui monitoring biaya dan proyek. Tindakan-tindakan yang dilakukan shahibul mal (principal's) terhadap mudharib (agen's) ataupun proyek untuk memperkecil masalah agensi, dalam teori keuangan dikenal dengan incentive compatible constraint's.

Hal lain yang perlu dicermati selain kegagalan atau kerugian yang disebabkan oleh faktor eksternal, sama pentingnya bahwa kegagalan atau kerugian dapat disebabkan oleh faktor internal, misalnya kemampuan sumber daya manusia yang kurang memiliki integritas yang baik, kemampuan menganalisa kurang cermat, maupun kelemahan fungsi pengawasan atau monitoring terhadap usaha mudharib ketika mengalami masalah dan tidak mampu memberikan solusi yang tepat.

Dari uraian di atas dapat diambil kesimpulan bahwa resiko yang akan dihadapi oleh pengelola manajemen resiko pada bank syari' ah dapat diringkas pada tabel berikut ini.

Tabel 2. Risiko Bank Syariah

\begin{tabular}{|c|c|c|}
\hline Type Resiko & Definisi & Ilustrasi \\
\hline Resiko Pasar & $\begin{array}{l}\text { Resiko yang terjadi } \\
\text { dari pergerakkan } \\
\text { harga atau volatilitas } \\
\text { harga pasar }\end{array}$ & $\begin{array}{l}\text { Harga pasar saham dalam } \\
\text { portofolio perusahaan } \\
\text { mengalami penurunan yang } \\
\text { mengakibatkan kerugian } \\
\text { yang dialami perusahaan. }\end{array}$ \\
\hline $\begin{array}{l}\text { Resiko } \\
\text { Pembiayaan }\end{array}$ & $\begin{array}{l}\text { Resiko karena counter } \\
\text { party gagal memenuhi } \\
\text { kewajibannya kepada } \\
\text { perusahaan (mudharib) }\end{array}$ & $\begin{array}{l}\text { Mudharib (misal pedagang) } \\
\text { tidak bisa membayar bagi } \\
\text { hasil, sehingga sehingga } \\
\text { mudharib mengalami } \\
\text { kerugian karena piutang } \\
\text { dagang tidak terbayar. }\end{array}$ \\
\hline $\begin{array}{l}\text { Resiko } \\
\text { Likuidi }\end{array}$ & $\begin{array}{l}\text { Resiko tidak bisa } \\
\text { memenuhi kebutuhan }\end{array}$ & $\begin{array}{l}\text { Perusahaan (mudharib) tidak } \\
\text { mempunyai } \\
\text { kas untuk }\end{array}$ \\
\hline
\end{tabular}




\begin{tabular}{|c|c|c|}
\hline & $\begin{array}{l}\text { kas, resiko tidak bisa } \\
\text { menjual barang/jasa } \\
\text { dengan cepat karena } \\
\text { ketidaklikuidan atau } \\
\text { gangguan pasar. }\end{array}$ & $\begin{array}{l}\text { membayar kewajiban (misal } \\
\text { bagi hasil). }\end{array}$ \\
\hline $\begin{array}{l}\text { Resiko } \\
\text { Operasional }\end{array}$ & $\begin{array}{l}\text { Resiko kegiatan } \\
\text { operasional tidak } \\
\text { berjalan lancar dan } \\
\text { mengakibatkan } \\
\text { kerugian kegagalan } \\
\text { sistem, human error, } \\
\text { pengendalian dan } \\
\text { prosedur yang kurang. }\end{array}$ & $\begin{array}{l}\text { Prosedur pengendalian } \\
\text { perusahaan tidak memadai } \\
\text { sehingga terjadi kelalaian, } \\
\text { dan kesalahan. }\end{array}$ \\
\hline
\end{tabular}

\section{Strategi dan Tindakan Preventif}

Setelah memahani skim pembiayaan mudharabah dan kemungkinan-kemungkinan resiko yang akan dihadapi, maka bank syari'ah, khususnya divisi manajemen resiko harus menentukan strategi dan langkah-langkah preventif untuk meminimalisir resiko yang akan terjadi sehingga pembiayaan mudharabah tidak mengalami kerugian. Adapun langkah preventif yang harus dilakukan adalah:

a. Bank-bank syariah harus mengetahui benar siapa mudharib-nya dalam arti karakter, integritas, dan aktivitasnya. Aspek religiusitas mudharib perlu mendapat perhatian. Tingkat religiusitas menunjukkan pada kondisi keberagamaan seseorang. Dalam konteks ini, religiusitas adalah keadaan dimana baik seorang shahibul mal atau mudharib memiliki pengetahuan dan menjalankan ketentuan-ketentuan dalam kontrak mudharabah, meninggalkan perilaku riba, melakukan pembayaran. Ketentuan ini disyaratkan untuk diikuti, dengan harapan dapat memperkecil masalahmasalah agency. Ketentuan-ketentuan tersebut dimungkinkan dapat membentuk pelaku kontrak mudharabah dapat menjalankannya dengan benar dan dapat mengurangi atau mencegah terjadinya perilaku curang, seperti perilaku tidak jujur atau aktivitas lain yang dalam teori keuangan disebut dengan moral hazard.

b. Pengalaman mudharib dalam mengelola usahanya. Pengalaman adalah pelajaran yang berharga dan tidak di dapatkan dalam dunia pendidikan. Semakin lama pengalaman seseorang dan fokus terhadap usahanya maka semakin mengenali seluk beluk dan permasalahan pada usaha yang dikelolanya. Bank syari'ah yang membiayai sistem mudharabah pada mudharib yang ahli dan 
pengalaman pada bidangnya, maka tingkat kegagalannya semakin kecil.

c. Untuk memastikan bahwa mudharib tersebut memiliki track record yang baik dalam usahanya maka bank syari'ah dapat melakukan bank checking untuk mengetahui apakah mudharib mempunyai pembiayaan bermasalah terhadap lembaga keuangan lain. Sedangkan untuk mengetahui pengelolaan usahanya bagus dan mendapat kepercayaan baik dari supplier maupun customer, bank syari'ah dapat melakukan trade checkingsecara random tentang pembayaran hutangnya lancar dan tepat waktu. Bila secara bank checking maupun trade checking baik maka dapat dikatakan bahwa mudharib orang yang berkomitmen dan bersungguh-sungguh dalam mengelola usahanya.

d. Meskipun dari segi karakter, integritas, dan pengalaman kerja baik sampai perjanjian kontrak mudharabah ditanda-tangani, namun terkadang kondisi seseorang apabila dihadapkan pada kondisi tertentu yang membuatnya tersudut maka perilaku itu dapat berubah. Untuk mengamankan kondisi tersebut, maka bank syari'ah dapat meminta jaminan. Dalam Fatwa Dalam Syari'ah no. 7/DSN-MUI/IV/2000 tentang pembiayaan mudharabah (qiradh). Diatur hal-hal yang berkaitan dengan pembiayaan mudharabah (penyaluran dana yang di lakukan Lembaga Keuangan Syari'ah/LKS) diantara memuat pada prinsipnya dalam pembiayaan mudharabah tidak ada jaminan, namun agar mudharib tidak melakukan penyimpangan, LKS dapat meminta jaminan dari mudharib atau pihak ketiga. Jaminan ini hanya dapat dicairkan apabila mudharib terbukti melakukan pelanggaran terhadap halhal yang telah disepakati bersama.

e. Ada baiknya mudharib yang akan dibiayai oleh bank syari'ah telah berjalan beberapa tahun dan memiliki laporan keuangan yang telah diaudit oleh akuntan publik yang memiliki reputasi yang baik. Dengan mendapatkan data laporan keuangan selama beberapa periode, maka analisis pembiayaan bank syari'ah akan mengetahui kondisi keuangan pihak mudharib. Bila tren-nya bagus, artinya usahanya tumbuh dan berkembang dengan tingkat profit yang naik setiap tahunnya, maka resiko kegagalan pembiayaan mudharabah dapat diminimalisir.

f. Apabila perusahaan mudharib yang akan dibiayai memiliki tempat usaha yang rentan terhadap kejadian kebakaran, gempa dan lainnya, alangkah baiknya bank syari'ah mengantisipasinya dengan mengikutkan dalam persyaratan akan agar tempat usaha harus diikutkan asuransi kerugian syariah. Demikian pula bila usaha itu milik perseorangan maka ada baiknya mudharib diharuskan 
mengikuti asuransi jiwa syari'ah. Ini perlu dilakukan sebagai langkah antisipasi bila terjadi pada tempat usaha maupun pemilik usaha (mudharib) tersebut.

g. Bank-bank syari'ah, termasuk BPR syari'ah membentuk divisi atau bidang penyelamatan dan pembiayaan bermasalah. Bidang ini secara khusus menangani restrukturisasi pembiayaan bermasalah. Disini diperlukan sumber daya manusia yang ahli dalam bidang tersebut sehingga analisis terhadap proses restrukturisasi benarbenar kedepannya tidak terulang lagi. Bila dimungkinkan, bank syari'ah dapat bekerjasama dengan seseorang atau konsultan yang ahli dalam bidangnya sehingga proses restrukturisasi akan berhasil.

h. Bank-bank syari'ah harus meningkatkan kompetensi sumber daya manusia agar bisa mengatasi pembiayaan bermasalah dan mampu melakukan restrukturisasi pembiayaan syari'ah. Untuk itu pihak bank syari'ah harus membekali dengan pelatihan dan pengembangan, job trainning, magang dan lain sebagainya secara berkelanjutan sehingga memiliki ketrampilan yang baik dalam menganalisis rencana pembiayaan mudharabah maupun mengatasi pembiayaan bermasalah bila usaha mudharib menunjukkan gejala tidak sesuai yang diinginkan (on the track).

i. Bank syari'ah harus terus memperketat standar underwriting dan secara proaktif memonitor nasabah dalam sektor industriyang terkena dampak perlambatan ekonomi secara umum.

j. Perbankan syari'ah harus membuat kebijakan yang ihtiyath (hatihati) sesuai dengan prinsip prudential dalam pemberian pembiayaan, tidak boleh didesak oleh pengejaran target atau pengaruh lain-lain.Artinya harus menghindari conflict of interest baik antara pengelola bank dengan pihak mudharib, antara atasan dan bawahan bank syari'ah, maupun antara account officer(analis pembiayaan) dengan pihak mudharib.

k. Perbankan syari'ah harus bisa mengendalikan dominannya portfolio tertentu termasuk di dalamnya mencakup resiko konsentrasi pembiayaan sehingga resikonya bisa dimitigasi dengan baik. Jika sudah terlanjur, dapat di atasi dengan sell down atau risk participation, atau jika aktivanya berupa Kredit Perumahan Rakyat (KPR), bank syari'ah bisa ikut sekuritisasi sebagian asset pembiayaan tersebut.Jadi bank syari'ah jangan sampai terpesona dengan bisnis yang sedang tren dan terkadang sifatnya temporer, atau bank syari'ah jangan sampai latah melihat jenis bidang usaha yang dibiayai oleh pesaingnya. Kondisi ini bukan jaminan bahwa keberhasilan pesaing yang terkonsentrasi pada bidang usaha tertentu akan dialami juga. Bank syari'ah dalam melakukan pembiayaan jangan terkonsentrasi pada satu atau dua bidang 
tertentu saja. Kondisi ini dapat berakibat fatal jika dominannya portofolio mengalami kebangkrutan atau kegagalan. Bank syari'ah hendaknya menyebar resiko dengan melakukan pembiayaan pada berbagai sektor bidang usaha. Seandainya satu sektor bidang usaha mengalami kemunduran maka tidak akan berdampak pada Non Performing Finance bank syari'ah.

1. Perbankan syari'ah harus istiqomah (konsisten) dengan model bisnis. Perbankan syari'ah harus meriset dan mengkaji terlebih dahulu potensi pasar dari suatu bisnis. Pertanyaan seperti berapa lama potensi pasar bertahan? Adakah produk dari bidang usaha tersebut ada penggantinya (substitusi)? Apakah jumlah pesaing banyak atau sedikit? Dan lain sebagainya. Analisis pasar perlu dilakukan secara mendalam agar jangan sampai sebelum perjanjian akad mudharabah berakhir usaha mudharib mengalami kegagalan. Dari hasil analisis pasar ini, maka bank syari'ah dapat melakukan pembiayaan dengan jangka waktu yang tidak terlalu lama, sehingga kegagalan dapat diantisipasi.

m. Sesuai dengan POJK (Peraturan Otoritas Jasa Keuangan), bank syari'ah wajib membentuk cadangan kerugian penurunan nilai (CKPN) atas aset keuangan dan non keuangan sesuai dengan standar akuntansi keuangan syari'ah yang berlaku. Kondisi sangat urgent untuk mengantisipasi bila ada mudharib mengalami permasalahan dalam usahanya yang mengakibatkan pembiayaan menjadi bermasalah dan menggangu cash flow lembaga bank syari'ah.

n. Melakukan monitoring yang intensif dan kuat. Dalam kondisi nasabah lancar sekalipun, monitoring tetap dilakukan. Monitoring pembiayaan yang lancar merupakan pembinaan yang terus menerus dilakukan kepada nasabah (mudharib).Strategi ini seharusnya dilakukan oleh bank-bank syari'ah yang rendah NPFnya. Fokus dan prioritas atas nasabah dengan jumlah pembiayaan yang besar. Hal ini perlu dilakukan karena apabila beberapa nasabah besar mengalami kegagalan dalam usahanya dan pembayaran bagi hasil serta pengembalian modal terganggu, maka akan berdampak pada tingginya NPF bank syar'ah tersebut, sehingga tingkat kesehatan bank syariah akan turun.

o. Bank syari'ah harus memiliki Pedoman Sistem Pelaporan Pelanggaran (Pedoman SPP) atau lebih dikenal dengan istilah Pedoman Whistleblowing System yang dapat digunakan perbankan syari'ah dalam mengembangkan manual sistem pelaporan pelanggaran di perbankan syari'ah.

p. Yang perlu diperhatikan dalam menghadapi pembiayaan bermasalah bank tidak boleh melakukan penyelesaian pembiayaan 
bermasalah semata-mata dengan cara plafondering, yaitu kapitalisasi margin dan biaya bank yang tidak dapat dilunasi oleh mudharib. Biaya dan margin tertunggak tersebut ditutup dengan menaikkan limit pembiayaan mudharib sehingga tunggakan tidak terlihat lagi karena telah berubah menjadi pembiayaan efektif atau tambahan hutang dalam batas limit pembiayaan yang baru.

\section{KESIMPULAN}

Dari uraian di atas maka dapat disimpulkan bahwa perekonomian Indonesia saat ini mengalami trend positif dan pemerintah mendorong tumbuhnya perekonomian baik melalui bentuk peraturan maupun kemudahan di bidang investasi, terutama di sektor perbankan syari'ah. Penduduk Indonesia yang mayoritas beragama islam dan hampir sebagian besar berusia produktif merupakan peluang dan kesempatan bagi bank syari'ah untuk berkembang. Namun demikian, pihak bank syar'ah dalam menjalankan operasionalnya tetap memperhatikan aspek kehati-hatian dan profesionalitas. Dari beberapa produk pembiayaan yang ditawarkan oleh bank syari'ah pembiayaan yang beresiko tinggi adalah pembiayaan mudharabah karena modal uang yang harus disertakan 100\% dari kebutuhan proyek yang dibiayai. Jadi apabila mengalami kegagalan akan beresiko pada tingkat likuiditas bank syari'ah tersebut. Oleh karena itu, untuk meminimalisir kegagalan dalam pembiayaan mudharabah perlu pengelolaaan manajemen resiko dan strategi pengamanan pembiayaan sebagai upaya tindakan preventif sebelum melakukan pembiayaan mudharabah.

\section{DAFTAR PUSTAKA}

Ascarya, Akad dan Produk Bank Syariah, PT. RajaGrafindo Persada, Jakarta, 2007

Darmawi, Hermawan, Manajemen Resiko, Bumi Aksara, Jakarta, 20016

Dwiharsono, Sonni, Manajemen Resiko, Yayasan Pengembangan Ilmu Asuransi, Jakarta, 1996

Kasmir, Bank dan Lembaga Keuangan Lainnya (Edisi ke Enam), PT. Raja Grafindo Persada, Jakarta, 1998

Muhammad, Manajemen Bank Syari'ah (Edisi Revisi Kedua), UPP STIM YKPN, Yogyakarta, 2011

Pradja, Juhaya S, Ekonomi Syari'ah, CV. Pustaka Setia, Bandung, 2012.

Wiroso, Produk Perbankan Syari'ah, LPFE Usakti, Jakarta, 2009 